Perspectives in Biology and Medicine 43(2000):584-597.

\title{
AESTHETICS IN THE SWAMPS
}

\author{
HOLMES ROLSTON III*
}

\begin{abstract}
Next began the muskegs, which almost entirely stood under water; these we had to cross for miles; think with what misery, every step up to our knees. .. . The whole of this land of the Lapps was mostly muskeg, here called stygx. A priest could never so describe hell, because it is no more horrible. Never have poets been able to picture the Styx so foul, since that is no fouler.-CAROLUS LINNAEUS (1732) [1, vol. 1, pp. 141-42]

When I would recreate myself, I seek the darkest wood, the thickest and most interminable and, to the citizen, most dismal swamp. I enter the swamp as a sacred place, a sanctum sanctorum. There is the strength, the marrow of Nature.-HENRY DAVID THOREAU (1862) [2, p. 228]
\end{abstract}

\section{The Most Misunderstood Landscape}

Even the father of modern biology hated muskegs, confirming how wetlands are the most misunderstood of the landscapes. Typically, we do not dislike land; we do not dislike water. But we dislike land-water, the muddy, mucky places where the land and the water mingle. Mountains and valleys, sky and clouds, sea and shore, rivers and canyons, forests and prairies, steppes and even deserts - none of these images have "ugliness" built in to them. But swamp, bog, and mire do. A "beautiful bog" or a "pleasant mire" are almost a contradiction in terms. Mountains are sublime; swamps are slimy.

There is nothing picturesque in a dismal swamp. Sometimes there are wide horizons, as in the Everglades, on the tundra, or on moors - but how monotonous! The only thing that might be of interest there are birds: waterfowl are the redeeming feature of wetlands. Otherwise, there is ooze and scum. Those who look for genetic dispositions that we inherit from

\footnotetext{
*Department of Philosophy, Colorado State University, Fort Collins, CO 80523.

Email: rolston@lamar.colostate.edu.
}

PBM 43, 4 (2000):584-597 @ 2000 by The Johns Hopkins University Press

584 Holmes Rolston III - Aesthetics in the Swamps 
our evolutionary past sometimes argue that humans naturally tend to enjoy savannah-type landscapes, open forests and grasslands, with running water, or lakes. This is the kind of environment we once evolved in, and feel secure in. They call this feeling biophilia. They also say humans have a biophobia for snakes and spiders. Maybe we have a biophobia for swamps.

Still, it is worth noticing that, contrary to the widespread dislike of swamps and mires, there have been occasional peoples who depended on wetlands and cherished them, such as the Cajuns in the bayous of Louisiana, or the Marsh Arabs of Southern Iraq, who live in the marshes of the Tigris and Euphrates Rivers.

Cities were often built on rivers, at first on the upland sites. There were often wetlands nearby, impeding the city's growth. These were regularly filled in the name of civilization and progress (though often remaining liable to flooding). Or the city grew around them as wastelands and sewage dumps, scars on the city scene. Hanging around the lowland cities, swamps are often a nearer, more daily encountered symbol of nature than wilderness, which may be a day's, or a week's, drive away.

There is some truth to these worries about swamps. Miasma, from a Greek word for "pollution," was poisonous air rising from the rotting bogs. Stagnant water is bad water; good water flows. Malaria means "bad air," and the disease was more often caught by those who lived near wetlands, breathing this bad air. That the disease was carried by a protist in mosquitoes, breeding in stagnant or slow moving waters, was unknown until the 1890s.

Swamps are damp, marshy, overgrown, rank, dismal, gloomy. They are uninviting places where you have to contend with insects while trying to keep from falling into the treacherous mud. Wetlands are wastelands. So, in the name of progress, people have been prompted to do something about them: put a road through them, or a railway; ditch them; drain them; if there was peat, dig it - put these lands to some higher and drier use. As a result, the world has lost half its wetlands since 1900, and wetlands may be the most threatened of all landscape types [3, p. 90]. So it is time to revisit wetlands. Others have pointed out their economic and ecological uses [3-6]; here the focus will be on aesthetics, as enriched by a scientific understanding of wetlands.

\section{Diverse and Prolific Wetlands: An Aesthetic Challenge}

To understand wetlands we need both some biological science and an intellectually maturing aesthetic sensitivity. When rightly perceived, these wastelands are sanctuaries for fauna and flora alike and places of stimulating beauty. Wetlands are found on every continent except Antarctica, and at every latitude from the tropics to the tundra. About 6 percent of the land surface of the Earth is wetland, and in the boreal regions this is 11 percent $[7$, p. 4]. Wetlands vary in size from small soggy areas and pools to 
vast tracts covering many thousands of hectares, both freshwater and brackish. So the diversity of wetlands is aesthetically (as it is also scientifically) a challenge and an opportunity.

The first misperception to be set aside is that wetlands are biologically wastelands. Wetlands can be high in biodiversity and biomass productivity, especially if open to hydrologic and nutrient fluxes. Wetlands have been described as being "among the most productive of all natural habitats," and as being "among the most fertile and productive ecosystems in the world," and have been found to produce "up to eight times as much plant matter as an average wheat field" [8, p. 162-99; 3, p. 9].

As one gets further north, life gets more difficult, and thus there is often less diversity in northern wetlands than in those in warmer regimes. Yet even when there is less variety - fewer species - than is found at lower latitudes, there is still exuberance. These fewer species are present in enormous numbers. Also, nutrients and oxygen can be problematic. As we will see, life's ingenuity under these difficult stresses can itself be aesthetically stimulating.

Water - it always becomes us to remember - is one of the vital features of Earth, which is the only planet we know with large amounts of liquid water. Water covers two-thirds of the Earth's surface. Water is vital to life anywhere on land, and wetlands are especially blessed with water (though there may be dry seasons as well). That is the principal secret of their remarkable fertility. If one includes as wetlands domestic rice paddies, then wetlands feed half the world.

An initial challenge is to separate the kinds of wetlands. The wide varieties of wetlands and the varieties of peoples experiencing them over many centuries have generated a rich terminology. Scientists try for more precision, but also use various classifying schemes $[5,7]$. Detailed judgments must be reserved for wetland scientists, but even a list of types is enough to show that there is a smorgasbord of wetlands: bogs, marshes, mires, muskegs, peatlands, palsa bogs, fens, swamps (used rather differently in Europe and in North America), wetland moors, wetland prairies, tidal salt marshes, mangrove wetlands, river floodplains and deltas, even wetland alluvial fans, such as the Okavango delta. This diversity bears on what kinds of aesthetic experiences are possible.

Wetlands are often rapidly changing: some may fill in with debris, others may vary with the seasons and with climate change. At the same time, wetlands considered as a biological phenomenon are often long-lived and constantly present throughout Earth's evolutionary past, and there is no cause for wetlands not to persist indefinitely in the future. Like the forest and the sea, or mountains and rivers, wetlands are a form of community that Earth has regularly been producing, and in that sense, wetlands are one of the archetypes of creation. The marshes have strands of continuity extending far beyond the relatively short spans of human civilization. 
Wetlands are places that arouse the senses. There is something untamable about them - at least there was until we built bulldozers. The very fact that mires are so difficult to put to good use triggers a relapse into accepting the "uses" to which nature has put these places. Wetlands are places where humans have to take care, since for the most part they are not the home habitat of Homo sapiens. There is something about the lack of firm footing that upsets us: we want to stand on a rock, on terra firma, not on sinking sand. In a quivering mire, we can't plant feet or crops.

A mire - we first think - can't be pretty, because it is impassable. A swamp is the archetype of the obstacles on Earth. There are roads into the fields and across the countryside. One can sail on the seas, take boats on the rivers. Mountains, though difficult enough, have their trails and passes. But in the swamp, no one can get anywhere. We have to take big boots, or waders, and are ever fighting the water. In northern wetlands, we are also fighting the cold. There are the insects, especially in summer, many of them blood-seeking. A long-time inhabitant once said, "Any fool can appreciate mountain scenery. It takes a man of discernment to appreciate the Fens" [9, p. 58].

\section{Mires and the Primeval}

Mires bring a deeper experience of time than we often experience. The slowed processes of decay underwater keep the evidences of former life close to the surface, and regularly before our eyes. The waterlogged remains are oxygen starved, compared to terrestrial sites, and decay slowly. Water-logged logs lie there decade after decade. There is a soggy thatch of dead plants. If bog waters contain sufficient tannic acid, the outer layers of an animal body can begin to be preserved by tanning. A human corpse 2,000 years old was discovered in a Danish bog in 1950, remarkably well preserved. This natural mummy had sharp facial features, and even his whiskers were intact [9, pp. 180-84]. Some 2,000 bodies have been found in European bogs [10]. The layers of peat form a sort of time capsule, a history book. One experiences that past lingering in the present. Wetlands reflect processes that are much older, more everlasting, and mightier than our human powers, even if the fearful power of the human mind and hand is, today, what most threatens these mires and bogs.

Although wetlands are, geologically speaking, comparatively recent landscapes, what we encounter there brings the experience of natural history. The peat suggests the Pleistocene and before. Even those not well educated in natural history are still aware that peat is ancient vegetation. The Finns, for example, perhaps more than those in any other nation, live with the legacy of the Pleistocene on their landscapes, so abundant with wetlands. The retreat of the glaciers left a Finnish landscape of lakes, scoured hollows, kettles, bogs, and mires. Many Finnish mires are thought to have 
existed continuously for 8,000 years [11, p. 48]. The peat can be interpreted as the rottenness of the last 8,000 years. Or it can be seen, if one studies the pollen preserved therein, as a record of life in these wetlands, ongoing with vigor for 8,000 years.

The record of the past, left in the debris, can also be complemented by finding relict species still alive and flourishing. Wetlands typically are better than drier sites for ferns, primitive plants which still must accomplish their fertilization in water droplets, and a luxuriant growth of ferns gives a sense of deep time. In the United States, our three most showy ferns are found in such sites: the cinnamon fern (Osmunda cinnamomea L.), the royal fern (O. regalis L.), and the interrupted fern (O. Claytoniana L.). Ferns offer a glimpse into the Devonian and subsequent periods when ferns dominated the flora.

In the wetlands there will be club moss, Lycopodium, a plant with an ancient past, going back to the Devonian period. They were among the first plants to discover how to make water carrying tissue and to develop true roots, leaves, and stems. With this discovery their ancestors grew quite large, as tall as trees, and once they were dominant on the landscape. The surviving Lycopodiums are smaller, unable to compete with the subsequently developing gymnosperms and angiosperms, but there they are like elfin pines. Their evergreen foliage is so aesthetically pleasing that, especially in the winter when little else is available, they are too much collected for Christmas decorations.

There will be also be horsetails and scouring rushes, Equisetum, with a lineage that goes back 400 million years, again to the Devonian period, when their ancestors bore lush foliage and filled the landscape. These are plants so atypical that a newcomer to the swamps will pause to wonder what on earth they are.

Mosses are abundant in mires. In the mosses, the evident plant is the gametophyte, which is the ancient, primitive condition in the flora, with the sporophytes inconspicuous. Only much later in evolutionary history did the sporophyte generation became the plant body that we know as the flowering plants. But lest we think that such primitive plants were somehow less ingenuous than the later ones, consider Sphagnum. Sphagnum, so important in many wetlands, has two kinds of cells: large hyaline ones, which are not alive, and small photosynthetic ones, where the living takes place. This structure gives Sphagnum its unusual capacity to hold water, 100 times its own weight, an absorbent capacity far greater than cotton. When the hyaline cells are only partially filled, this also gives Sphagnum is capacity to form spongy hummocks and floating mats, and thus to survive in wetlands where little else can. In turn, this becomes a surface for a lighting insect or from which a frog can feed, In time, ferns and other plants will take root there.

One does have to be educated into such facts to appreciate these relics of the past; still, once known, one enjoys the experience of deep time. 
And, even when relatively well educated, one wonders how much one is yet overlooking about the long-flourishing of life in these swampy places. We humans may get mired down there, but life does not. It is perpetually flourishing.

We may have trouble getting around in a marsh. But the cranes there go back 40 million years. For the waterfowl, there is good cover and plenty to eat. If you have both wings and feet - perhaps webbed feet with which you can both walk and swim, or long feet with which you can wade - a swamp is a fine home. It can help to see a swamp with a bird's eye view.

\section{Mires: The Graceful, the Ingenious, and the Unusual}

One needs a little extra skill to enjoy the flowers in the marshes. This is not always true, for there are many showy flowers, such as the blue flag (Iris versicolor L.). The iris, we can recall, was aesthetically pleasing enough to have adorned the brows of the sphinx statues in Egypt or to become the fleur-de-lis, emblem of the house of Louis VII in France. Iris was the goddess of rainbows; irises come in many hues and colors. The common European one of wet places is the yellow iris (Iris pseudacorus L.). The yellow pond lily (Nuphar) can almost be its equal.

Bogs are also where to find the lady slipper orchids, such as Cypripedium. Who is not excited to chance upon one, and more excited if there is a patch of half a dozen? The large, prominently veined leaves frame the waxy flowers of purple, deep pink, or yellow, with the side petals and sepals often in marked color contrast to the inflated, pouch-like lip. Smaller and more subtly stimulating, there will be buttercups (Ranuculus), with their distinctive glossy yellow petals, set strikingly against their green foliage.

Especially in the wetlands however (as is also true in grasslands), one is going to have to learn to appreciate flowers that are so inconspicuous looked at one by one that you need a hand lens to see them. En masse, however, these minute flowers can produce some quite aesthetically pleasing forms. Think of the feathery plumes of a grass like reed grass (Phragmites communis Trin.), waving in the wind, or the shimmering panicles of wild rice (Zizania aquatica L.). One can learn to enjoy alder catkins, dangling in the wind, brown but with a subtle purple hue, with something added in excitement because they unfold in early spring, when little else is going on. There are no showy petals; no one looks at the individual flowers. But the sinuous, flexible catkins of the male flowers, contrasting with the erect, stiff cones of the female flowers, innumerable in a dense thicket of alder, have their own aesthetic appeal.

There will likely be cranberries (Vaccinium) in the bog. Each plant is small, but find a bell-shaped flower, as graceful as any craftsman's urn, a charming silken white, and you will admire it. When the flowers are gone, the crimson berries dot the swamps, often in sizeable patches. First you 
enjoy visually the red berries against the dark leathery leaves. Later you may enjoy their tart taste. If you cannot find cranberries, then find heather (Calluna); the flower, though purple, has the same graceful urn.

In the swamps, one can learn to enjoy the great bullrushes (Scirpus validus Vahl), with their gently curving blades. Cotton grass (Eriophorum, a sedge), becomes spectacular when backlit by the sun, its fluffy white heads contrasting with the darker bog. One needs to learn to enjoy the sweep of a field of sedges (Carex); look closely, they typically have triangular stems. Cattails (Typha), even through the frosty winter days, stay prominent with their dark brown cylinders, perched on straight spears, keeping a kind of sentinel over the marsh. Each head is composed of thousands of minute flowers, becoming minute seeds with long hairs, which burst forth across the fall and winter into fluffy masses, releasing the seeds to the winds.

Duckweed (Lemna) is so small that each floating plant is only a few millimeters in diameter, with a single dangling root. It is about the least a plant could be and still be something recognizable as a plant: one tiny leaf and one tiny root. These little marvels have a remarkable ability to replicate, and they form a smooth, pale, pleasantly green surface that carpets large areas of quiet water. Nothing moves, until perhaps a frog or a turtle pokes its head through, with these tiny green bits clinging all over its face. Tiny though they are, the duckweeds have managed to colonize much of the world, and are found throughout Europe as well as America.

Wetlands are likely places for odd plants, like jack-in-the-pulpit (Arisaema atrorubens [Ait.] Blume). Who does not find the encounter with one aesthetically stimulating? There are a couple of three-parted, rather translucent leaves like a parasol over jack in his pulpit. The flower is really a pleasingly striped modified leaf called a spathe, surrounding and forming a canopy (like an old-fashioned pulpit) over the green spike bearing tiny flowers. Another, early spring, find is the skunk cabbage (Symplocarpus foetidus [L.] Nutt.), whose large, bright green leaves contrast with the still wintry, brown, ever-dreary forest floor. Later, tiny, delicate, flesh-colored flowers are borne on a thick finger-like stalk, a spadix, with an encasing spathe.

Insectivorous plants have adapted to the nitrogen-deficient soils of bogs by reversing the usual trophic pyramids, where insects eat plants. Now plants eat insects. Sundews (Drosera) are small, but often one spots a tiny flash on the wet ground. The droplets that sparkle - the "dew" sparkling in the "sun"—are a powerful gummy adhesive, held aloft on tentacles to trap an unsuspecting insect, who is attracted by the coloration, the sparkle, and the sweet sensations that the sundew exudes. The larger pitcher plant (Sarracenia purpurea L.) has worked out its trapping in a quite different but still ingenious way. Curious leathery evergreen leaves are formed into hooded traps; the unsuspecting insect is lured into the vessel and caught by downward pointing bristles. 
Still another way has been worked out by the Venus flytrap (Dionaea muscipula Ellis.), a mechanical marvel and probably the most effective prey-trapping land plant. The leaves are hinged, fringed with stiff long bristles, and exude a sweet nectar. There are trigger hairs on the midrib, which, when touched twice by an insect, release the hinged leaf to snap quickly shut. The marginal fringes, like eyelashes, interlock and form a cage where the insect is held and digested. The capture takes only a second or two. Then the leaf secretes, over several days, digestive enzymes that break down the insect protein into amino acids and peptides. If the plant reacts to a falling twig or a windblown pebble, the leaves are soon reset. In flower, there is a showy cluster of five-petaled white flowers, borne at the tip of a leafless stalk.

Still another way of trapping has evolved in the bladderwort, rootless and water borne, which is studded with tiny traps - up to 600 on a single plant which feature hair triggers so sensitive that a touch from microscopic organisms, such as water fleas, diatoms, and desmids, can set them off. The hair triggers protrude outside the trap, which is closed and set with a partial vacuum. When the bladderwort's prey accidentally touches the hair, the door of the trap opens in a quarter of a second, and with a swish the prey is sucked in as water refills the partially empty sac, the door quickly reshutting.

Eating insects is always interesting plant ingenuity, and one wonders what to make of it philosophically and aesthetically. Is the behavior just bizarre? Or is there a chance for a moment of truth? Here is "nature red in tooth and claw," now even with the plants, who otherwise might be thought less predatory, since they photosynthesize their own food. But everyone knows that life preys on life; the ecological networks of life-support and value capture are part of the beauty of life. Even in the plants there can be an inventive genius, all the more so where there is adversity. This is passing strange and wonderful.

This survey has thus far featured the plants, because they are what one inevitably sees, though they can require closer attention. Lingering in the marshes, however, one ought not to overlook the invertebrates, again mostly small: mollusks, such as the snails and mussels; crustaceans; insects, such as the dragonflies and butterflies. Consider the water fleas (Daphnia), for instance. A tiny Daphnia is only a millimeter long and carries its young in a transparent pouch on its back. Under a hand lens, one can see 10 or 20 embryos whirling around in the brood chamber of each female. One species produces a brood of eggs every two days; in 60 days, its descendants could number 13 billion. That is marvelous fertility. Of course, the young do not all survive, since this prolific crustacean is a diet staple for fish and other marsh life. Such food chains too are part of the marvel of life. When you admire the heron in flight, remember that it is powered by energy from the fish it has caught, and the fish are powered by such organisms as these water fleas, which are powered in turn by the photosynthetic algae and other plants that they eat. 
In warmer fresh-water marsh pools, there are whirligig beetles, which get their name from their habit of spinning rapidly about on the water surface, like miniature speedboats. With their heads at water's level, they have compound eyes divided into two parts, one for seeing above the water surface, and one for seeing below it, a useful adaptation for catching insects both under the water and on it. Again, we have a reminder of the ingenuity of life, which can be splendidly adapted to the two domains, above and below water, which make wetlands so uninviting to us.

The story could be continued, even with the mosquitoes, the vampires of the marsh. Mosquitoes are marvels too, in the way in which the sharp, spiked mouthparts of the female can penetrate the tough skin of many birds and mammals. Or we could look at the vertebrates, the fish and frogs, the amphibians and reptiles, such as the salamanders and the turtles. Or we can admire what we call - perhaps again with a biased misperceptionthe higher animals: otters, muskrats, mink, foxes, bobcats, lynx. Wetlands are often good for wildlife, just because humans are not so often or so easily there. All these species are present in their niches - or at least they were, until we ravaged their habitats in the name of progress.

Above all, we must not forget the water birds, with their adaptations for life in the wetlands. First and always, of course, there are the ducks: mallards, pintails, shovelers, buffleheads, teal. Their colors are striking and bold. The males in spring, with their iridescent greens and purples set against red and white, are living color. Indeed they reach extremes of coloration that one could almost call gaudy. Be careful, though, not to make the mistake of thinking that the subtly colored females, adapted more for camouflage than for mating display, are less beautiful.

The display in color combines with a display of powers of flight. Is there anyone, visiting the wetlands, who has not enjoyed a wedge of geese flying overhead? When the birds are high in the sky, one wonders how far they have come, and remembers the long migrations of many such waterbirds. Their capacities for orientation are still not well understood, and remain one of the marvels of natural history. Further, the long migration is only one display of their powers of flight. One discovers another when, unaware in the rushes, one stumbles upon a hiding place and flushes a pair of ducks into a startlingly rapid take-off.

There are also the blackbirds, coots, grebes, cormorants, pelicans, mergansers. To watch a gallinule or a jacana confidently striding over the floating lily pads with its oversized feet is a memorable experience. Or to watch a marsh hawk soaring low over the mires. Or great blue herons with their heavy flight. One cannot have cranes without marshes; so what one has to appreciate is not cranes, but cranes in marshes. Watching the somewhat ungainly flight of the cranes, it is not hard to imagine that one is watching a flying reptile on a much younger Earth, and one is plunged back into time. 
So one gets both a sense of time and of distance. A feature of the birds is that they depend on the wetlands but migrate, and thus are part of the common heritage of many other ecosystems, and of many other persons, who live thousands of miles from the mires.

Perhaps the most celebrated of our northland waterbirds is the loon; here the striking colors combine with a still more striking call. The call of the loon is likely to be the last aesthetic experience of a day by the water. Well into the night, the haunting call reminds hearers that the lakelands are still there, as is this ancient bird. Next day, the sight of a loon reveals another remarkable power in birds: their capacity for swimming. Submerging and emerging, loons, like the grebes, can be appearing and disappearing all over a body of water. Look quickly, or the bird will be gone; and the experience, again, is of life alert and on its own, as it has been since before humans evolved on the planet.

\section{Ecosystemic Aesthetics: Beauty and Adapted Fitness}

Aesthetic experience of marshlands, like aesthetic experience of wild nature in general, must pass beyond what is scenic or pretty, beyond what strikes human fancy for its form and color. Mires and bogs are places where wildness can more easily be preserved and experienced. We must enter into an appreciation of what the marsh ecosystem is in itself, when we are not there. Then, of course, there is no aesthetics present, for while the animals may have their pleasures, we do not think that turtles evaluate jack-in-the-pulpits aesthetically. Nor do the cranes necessarily admire the fields of rushes and sedges undulating in the wind. They operate within their niches, their sectors, and cannot take a view of the whole, whether scientifically or aesthetically.

Humans can do both, and they enjoy swamps, especially when scientific understanding leads to aesthetic stimulation. While mountains and canyons can be enjoyed as found art, a sort of landscape waiting for the painting, even when aesthetic experience falls short of a living landscape, in the swamps found art is harder to come by, certainly at the landscape scales. Yes, the flowers brought into focus one by one can be lovely, as with the iris and orchids. But not the ecosystem-that seems much more chaotic and messy. The swamp is not there to afford an aesthetic experience. But what is there is remarkable, and aesthetically stimulating.

If no aesthetic experience, what is really there? Marvelous order, mixed with disorder that stimulates the order. It is relatively easy to be convinced that wetlands do contain, here and there, some aesthetically stimulating items. Still, the system as a whole appears to be a mess. But is that really so? Plant systematics works just as well in the swamps as in the mountains; swamps are no more disorderly or orderly than grasslands or deserts. Adapted fit there, however, may require some special effort, some ingenu- 
ous achievement. There is a kind of order that arises spontaneously and systematically when many self-actualizing organisms jostle and seek their own lifestyles, each doing their own thing, and forced into informed interaction with other organisms.

Any ecosystem systematically generates spontaneous order, an order that exceeds in richness, beauty, integrity, and dynamic process the order of any of the component parts, an order that feeds (and is fed by) the richness, beauty, and integrity of these component parts. The kind of creativity in individual organisms (regenerating a species, pushing to increase its kind) is used to produce, and is checked by, another kind of creativity (speciating that produces new kinds, interlocking kinds with adaptive fit, plus individuality and looseness). We get diversity, unity, dynamic stability, spontaneity, a life-support system, a fortunate place, the wonderland of natural history, the miracle of creation - all of which is quite as present in wetlands as in the drier lands that we might prefer as more comfortable or more scenic.

When humans evaluate ecosystems, especially those that, like swamps, seem rather chaotic, we have an initial tendency to think that decentralized order is of low quality because it is uncentered and not purposive; there is no center of experience or control. There are not the neat lines and curves of suburbia, or the managed look of a well-kept farm. But wetland ecosystems are a fertile order just because they integrate (with some chaotic looseness) the know-how of many diverse organisms and species. Ecosystems are in some respects more to be admired than any of their component organisms, because they have generated, continue to support, and integrate tens of thousands of member organisms. The ecosystem is as wonderful as anything it contains. In nature there may sometimes be clumsy, makeshift solutions. Still, everything is tested for adaptive fitness. Producing adaptive fits and eliminating misfits, the ecosystem is the satisfactory matrix, the generative source of all it contains.

Wetlands plants can tolerate extremes of moisture, nutrients, and oxygen in the soil. Marshes and mires are a special form of wilderness, remarkable places for adapted fit. They are complex networks connected in biotic community, as we learn when we try to re-create them. Most wetland restoration or mitigation has failed. One can't just dump some water on land and have a wetland. Wetlands have their own integrity, a life-rich genuineness.

Take the iris, whose colors were praised earlier. The flowers are remarkably adapted to ensure cross-pollination. The stamens are positioned so that their pollen grains cannot easily reach the stigmas of the same flower. Bees are especially attracted to their showy flowers. The nectar is placed so that bees go downward and get dusted with pollen, which is carried to another flower. Or recall the spathe of the skunk cabbage, encasing the delicate flowers; that is an admirable arrangement for protecting the flowers against the cold days that punctuate the spring thaw. The stink might not be pleasing; but put that in a different perspective: the odor is that of 
carrion, which attracts the needed insects for pollination. One should not admire the iris and hate the insects. One should love them both, in their interconnectedness.

Everywhere one looks, there are adaptations for survival This becomes a symbol of the whole and invokes the marvel of life. Wetland soils are often nitrogen-deficient, and we noted how insectivorous plants solve that problem. While one is enjoying the sinuous alder catkins so early in the spring, one can further marvel at the way they have solved this nitrogen problem. On their roots are nodules filled with bacteria which are able to fix atmospheric nitrogen. Thus for millennia the alder have done something humans only learned to do in this century. That makes alder, otherwise of little economic use, quite a useful member of the aquatic biotic community.

A child looks at a lady slipper orchid and thinks it is pretty. More mature aesthetically, educated adults look at the Cypripedium and think of the plant in its adapted fitness and its struggle for life. Darwin said that from the shape of an orchid, he could predict an as-yet-unknown insect that must exist to fertilize it. We can look at flowers that are not showy at all, as the Carex in the mires are not, and predict the winds that will in their case do the pollinating, and still be moved.

Many plants, such as cattails (Typha), have learned to survive by vegetative reproduction, spreading by rootstocks. Although cattails also produce thousands of seeds, which they spread into the wind by downy bristles, this fail-safe adaptation enables them to bypass the seedling stage, a highly vulnerable process on the watery lands, and even more chancy when seeds are blown across the terrestrial landscape. The combination reproductive package works quite well, for cattails have found their way around much of the world, and cattails are as likely to persist as any plant in the wetlands. Reeds (Phragmites) have learned the same trick. The cattails have another trick too; their spongy tissue conducts oxygen down to the roots, and that solves the problem that so many other plants are unable to solve: how to survive in oxygen-deficient soil.

Larch, as a deciduous conifer, can tolerate unusual stress. One needs to remember that the larch is dealing with such stress when the trees one sees are stunted and shrubby, as they often are in the far north. Extreme waterlogging in the summer causes many tall trees to lean, producing spectacular "drunken forests." One has to learn to appreciate the leaning or stunted trees of the wetlands, just as one has to learn to appreciate the contorted, windswept banner trees at the tree line, another example of life hanging tough in extremes.

\section{Life Persisting Amidst Perpetual Perishing}

Peat bogs give us a sense of deep time. There is often also a sense of transience, more in some kinds of wetlands than others. The cattail is a 
key plant in changing wet soil into dry land: its thick mat of stocky, horizontally branching rootstocks traps decaying debris, building more soil. Water-loving plants invade the margins of a lake; as detritus collects, marsh-loving plants replace them; afterward the bog fills and shrubs and trees can enter. Meanwhile wetlands continue and are regenerated elsewhere on the landscape.

Wetlands do teach that everything is doomed to die, and the debris so evident from past life — now fallen, black, rotting — reminds us of this. Take a handful of the black ooze, a mixture of silt and partly decayed plants and animals that once lived here and have gradually piled up on the bottom. Wetlands are filled with corpses, and they remind us of our mortality. But life inevitably goes on. That handful of ooze may contain more living organisms than there are humans in the world. After one has become ecologically sensitive, the system takes on the qualities of a kaleidoscope, in which the accidental tumbling of bits and pieces, each with its own flash and color, constitutes a set of patterns of interdependent parts coacting, patterns repeated over time and topography, endlessly variable and yet regular, buzzing with life.

A lingering aesthetic experience of nature, always running subliminally, is of life persisting in the midst of its perpetual perishing. Think of a mire in winter. Is this a still and lifeless scene? Is there nothing but frozen beauty? Consider the way in which life is locked up in the cold. Life is there in the seeds and buds, and beneath the ground in roots and eggs, protected by the insulating layers of snow and ice. The animals may be starving, but there is beauty in their endurance before winter. The northland mires, especially in winter, can seem indifferent to life. But we must anticipate the summer's light. Even on a winter's night there is a kind of promise over the mires.

The shadows linger, for throughout the summer there are reminders of the winter. Strange bog patterns develop in regions of permafrost and frequent frost action. These include the remarkable geometries of frost wedge polygons, that of palsa bogs, and other mosaics of hills and ridges. These remind us that we are on a landscape shaped by the cold, and this is as true of the fauna and flora as of the geomorphology. In the short range all lose: death is inevitable, and the peat is proof of that. But then again in the long range life persists, phoenix-like, forever regenerated in the midst of its destruction. In that sense the peatlands are lands of promise; one experiences there with special force the dialectics of life.

In 1973, an October rainstorm created a layer of ground ice over the Canadian muskegs that, later, muskoxen could not break through to feed. Nearly 75 percent of the muskox population in the Canadian Archipelago perished that winter. Still, though stressed by the winter, the muskoxen are satisfactory fits in their ecosystems, and the muskeg ecosystem that seems so severe is also the nature that provides their life support. The muskoxen, 
decimated that one winter, continue on the tundra, living on for millennia, so well adapted to a polar existence that this is one of the few large animals to have survived the Ice Ages in North America. Survival-making it through, living on and on-is the last word, life's deepest beauty.

One rejoices in the passage of the seasons, especially pronounced in boreal wetlands. Each spring there is the spirited return of life, against the blasts of winter. With the passage of the millennia, for longer than anyone can remember, life has been challenged in the northland environments and has proved prolific. In June, at the summer solstice, there is hardly any night at all. But the dark is coming. And yet? At the winter solstice, one knows as surely as one knows anything that the spring will come again, and life will be resurrected. That is what is stimulating about a mire in a snowstorm, with a vague moving whiteness, turning gray as night approaches. The scene is somber, but never so somber as to veil the promise of life.

With such aesthetic experiences, one has come a long way from wetlands as wastelands. Thoreau in his swampy sanctuaries was nearer the truth than Linnaeus tramping his wetland hells.

\section{REFERENCES}

1. Linnaeus, C. Lachesis Lapponica, or a Tour in Lapland (1732), translated by J. E. Smith. 2 vols. London: White and Cochrane, 1811.

2. Thoreau, H. D. Walking (1862). In The Writings of Henry David Thoreau, vol. 5. New York: AMS, 1968.

3. Maltby, E. Waterlogged Wealth: Why Waste the World's Wet Places? Washington, DC: Earthscan, 1986.

4. Vasander, H., ed. Peatlands in Finland. Helsinki: Finnish Peatland Society, 1996.

5. Gore, A. J. P., ed. Ecosystems of the World, vol. 4A. Mires: Swamp, Bog, Fen, and Moor, General Studies, Amsterdam: Elsevier Scientific, 1983.

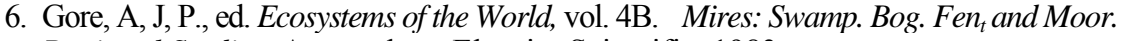
Regional Studies. Amsterdam: Elsevier Scientific. 1983.

7. Mitsch. W. J.. and J. G. Gosselink. Wetlands. 2nd ed. New York: Van Nostrand Reinhold. 1993

8. Niering. W. A. The Life of the Marsh: The North American Wetlands. New York: McGraw-Hill. 1966.

9. Coles. B.. and J. Coles. People of the Wetlands: Bogs. Bodies and Lake-Dwellers. London: Thames and Hudson. 1989.

10. Glob. P. V. The Bog People: Iron Age Man Preserved. Ithaca. NY: Cornell Univ. Press. 1969.

11. Ruuhijärvi, R. The Finnish mire types and their regional distribution. In [6]. 